\title{
PERKEMBANGAN KECERDASAN INTRAPERSONAL ANAK USIA DINI KELOMPOK B TK NEGERI PEMBINA KOTO BARU KECAMATAN KUBUNG KABUPATEN SOLOK
}

\author{
Nidia Angela ${ }^{1}$, Edi Hendri Mulyana ${ }^{2}$, Dadan Nugraha ${ }^{3}$ \\ ${ }^{1}$ Program Studi PGPAUD UPI Kampus Tasikmalaya \\ ${ }^{2}$ Program Studi PGPAUD UPI Kampus Tasikmalaya \\ ${ }^{3}$ Program Studi PGPAUD UPI Kampus Tasikmalaya
}

Email: nidiaangela@ rocketmail.com

(Received: Mei 2019; Accepted: Mei 2019; Published: Juni 2019)

\begin{abstract}
Some professional studies show that intrapersonal intelligence is one of the important intelligenceswhichto be owned and developed for the students besidethe other intelligences. Considering the importance of it, the education world should be aware about the importance of intrapersonal intelligence besides the other intelligences. The purpose of this study is to find out the intrapersonal intelligence development of children at Group B Pembina state kinderkarten Koto Baru Kubung district Solok regency. And to know the intrapersonal intelligence development of children in the self-discipline aspect, self-confidence, responsibility, expressing activities and capability to improve themselves. By using purposive sampling technique obtained data to be studied there are 15 child. The method of this research is descriptive method with qualitative approach. After analyzing the collected data, it shows that the intrapersonal intelligence development of children at group $B$ Pembina state kinderkarten Koto Baru Kubung district Solok Regency is very good development level (BSB), because, from 15 researched childrens there are 8 childrens who achieve very good development (BSB), 5 children who achieve according to the expectations development (BSH), and 2 children with achievement levels began to grow $(M B)$.
\end{abstract}

Keywords: Intrapersonal Intelligence, Development, Level of Achievement

\begin{abstract}
ABSTRAK
Berbagai kajian para ahli menunjukkan bahwa kecerdasan intrapersonal merupakan suatu bentuk kecerdasan yang penting dimiliki dan dikembangkan pada diri peserta didik disamping kecerdasan lainnya. Mengingat pentingnya hal tersebut, dunia pendidikan ini harus menyadari akan pentingnya kecerdasan intrapersonal disamping kecerdasan yang lainnya. Tujuan penelitian ini adalah untuk mengetahui perkembangan kecerasan intrapersonal anak kelompok B TK Negeri Pembina Koto Baru Kecamatan Kubung Kabupaten Solok. Dan untuk mengetahui perkembangan kecerdasan intrapersonal anak dalam aspek mandiri, disiplin, percaya diri, tanggungjawab, mangekspresikan kegiatan dan mampu memperbaiki diri. Dengan menggunakan teknik puposive sampling didapatkan data yang akan diteliti ada 15 orang anak. Metode yang digunakan adalah metode deskriptif dengan pendekatan kualitatif. Setelah dilakukan analisis terhadap data yang terkumpul diketahui bahwa perkembangan kecerdasan intrapersonal anak kelompok B TK Negeri Pembina Koto Baru berada pada tingkat pencapaian berkembang sangat baik (BSB), kerena dari 15 orang anak yang diteliti terdapat 8 orang anak yang berada pada tingkat pencapaian berkembang sangat baik (BSB), 5 orang anak yang berada pada tingkat pencapaian berkembang sesuai harapan (BSH), dan 2 orang anak dengan tingkat pencapaian mulai berkembang (MB).
\end{abstract}

Kata kunci: Kecerdasan Intrapersonal, Perkembangan, Tingkat Pencapaian 


\section{PENDAHULUAN}

Usia dini merupakan masa keemasan perkembangan anak yang sering disebut Golden Age, kerena di usia lahir sampai 6 tahun anak sangat peka atau sensitif untuk menerima stimulus. Masa peka setiap anak akan berbeda seiring dengan laju pertumbuhan dan perkembangan anak secara individual. Untuk itu orang tua maupun guru harus mengetahui laju pertumbuhan dan perkembangan anak, agar anak berkembang sesuai tahap perkembangan yang semestinya. Pada usia ini anak memulai perkembangan dan pertumbuhannya yang luar biasa, baik secara fisik, emosional, dan sosial. Pendidikan anak usia dini merupakan pendidikan yang paling mendasar untuk menjalani proses perkembangan dengan pesat dan fundamental.

Dalam UU No 20 thn 2003 tentang Sistem Pendidikan Nasional berkaitan dengan Pendidikan Anak Usia Dini yang tertulis pada pasal 28 ayat 1 yang berbunyi “ PAUD diselenggarakan bagi anak sejak lahir dan sampai usia enam tahun dan bukan merupakan prasyarat untuk melajutkan pendidikan dasar". Dan dilanjutkan dengan BAB 1 pasal 1 ayat 14 yang menyatakan bahwa :

"Pendidikan anak usia dini adalah suatu upaya pembinaan yang ditujukan kepada anak sejak lahir sampai dengan usia 6 tahun yang dilakukan melalui pemberian rangsangan pendidikan untuk membantu pertumbuhan dan perkembangan jasmani dan rohani agar anak memiliki kesiapan dalam memasuki pendidikan lebih lanjut."

Dalam UU tersebut sangat jelas bahwa anak usia dini yang menempuh pendidikan di lembaga PAUD hanya merupakan upaya pemerintah untuk memberikan ransangan kepada anak sejak dini, serta membantu pertumbuhan dan pekembangan anak. Baik Itu pertumbumbuhan dan perkembangan jasmani maupun rohani anak. Serta agar anak memiliki kesiapan untuk pendidikan selanjutnya dan lembaga PAUD bukan merupakan satu prasyarat untuk tenjang pendidikan selanjutnya.
Sebagaimana teori Montessori (dalam Yuliani, 2013: 108) bahwa

"Pembelajaran PAUD adalah membebaskan anak belajar menurut tempo dengan caranya sendiri dan materi yang dipilihnya sendiri dan ditentukan berdasarkan taraf kemampuan dan minat. Serta anak tidak perlu bersaing dengan anak yang lainnya atau dihambat kemajuannya agar sesuai dengan kelompoknya".

Dalam teori tersebut montessori mengatakan bahwa pembelajaran PAUD membebaskan anak belajar, memilih materi, dengan caranya sendiri dan ditentukan berdasarkan minat. Dan sangat penting bahwa anak tidak perlu bersaing satu samalain, kerena ini akan menghambat kemampuan anak dalam bereksplorasi. Berikan mereka ruang dan waktu untuk dapat mempelajari sungguhsungguh apa yang anak minati dan apa yang anak inginkan. Pastinya anak akan memfokuskan minatnya atau kemauannya hanya dalam bidang yang anak sukai dan dapat membuat anak berimajinasi dengan leluasa. Dan sebagai orang tua juga harus menerima semua potensi anak yang dianugrahkan tuhan kepada anak-anak.

Melihat anak-anak di kelompok B TK Pembina Negri Koto Baru saat pembelajaran di kelas, guru menyampaikan kegiatan apa yang akan dilakukan hari itu sedangkan siswa ada yang memperhatikan guru, ada yang asyik sendiri, bahkan ada yang main keluar. Masalah ini yang sangat menarik perhatian peneliti, kerena peneliti ingin mengetahui bagaimana keadaan kecerdasan intrapersonal anak. Agar dengan mengetahui kecerdasan intrapersonal anak, dapat membantu guru untuk mengetahui kelemahan dan kekuatan anak.

Pada saat pembelajaran ada anak yang fokusnya sangat baik, anak ini memperhatikan guru menyampaikan aturan dan kegiatan yang akan dilakukan. Anak yang fokusnya baik, akan melakukan kegiatan permainan yang disediakan oleh guru dengan tuntas atau bermain sesuai dengan aturan yang ada. Ada 
juga anak yang diam dikelas, tapi tidak melakukan kegiatan atau permainan yang disediakan. Anak ini diam dan sibuk dengan mainannya sendiri. Tapi anak ini bisa menciptakan sesuatu dari mainannya dan menceritakan apa yang dibuat, dan mengapa ia membuatnya, anak ini bisa menjelaskan dengan baik. Untuk itu peneliti ingin melihat kecerdasan lain yang dimiliki anak-anak di kelompok B TK Pembina Negri Koto Baru ini, khususnya anak yang memiliki kecerdasan intrapersonal. Karena pendidikan adalah suatu proses untuk membantu individu dalam megembangkan dirinya, sehingga mampu menghadapi segala perubahan dan permasalahan yang dihadapi. Hal ini sangat mengukinkan anak untuk memdapatkan kesempatan untuk mengembangkan secara optimal kemampuan atau kecerdasannya.

Kecerdasan merupakan ungkapan dari cara berfikir seseorang yang dapat dijadikan modal untuk belajar bagi anak, yang memiliki manfaat besar bagi diri sendiri dan untuk pergaulan dimasyarakat. Setiap orangtua menginginkan anaknya menjadi cerdas, tetapi untuk mewujudkan anak yang cerdas tidaklah mudah. Anak perlu mendapat kesempatan agar bisa mengembangkan seluruh aspek kecerdasan.

Menurut gadner (musfiroh, 2004) kecerdasan adalah kemampuan anak untuk menyelesaikan masalah atau menghasilkan produk yang dibuat dalam satu atau beberapa budaya. Sebagaimana seorang psikolog Harvard AS merumuskan Multiple Intelegences, ada delapan kecerdasan dasar yaitu kecerdasan linguistik, kecerdasan matematika logis, kecerdasan visual spasial, kecerdasan kinestetik, kecerdasan musikal, kecerdasan interpersonal, kecerdasan intrapersonal, dan kecerdasan naturalis. Menurut gardner, kecerdasan dapat bervariasi menurut konteksnya, anak cukup memiliki satu atau beberapa saja diantara delapan kecerdasan. Bila anak distimulus pada kecerdasan yang menojol, maka anak akan semakin mudah berkembang sesuai dengan kekuatan kecerdasannya.
Salah satu kecerdasan yang dikemukakan oleh Gardner adalah kecerdasan intrapersonal. Gardner dalam Yuliani (2013:191) mengungkapkan " kecerdasan intrapersonal adalah kemampuan diri seseorang untuk berpikir secara reflektif, yaitu mengacu kepada kesadaran reflektif mengenai perasaan dan proses pemikiran diri sendiri. Kecerdasan ini meliputi kekuatan memahami diri dan keterbatasan diri seperti: kesadaran akan suasana hati, maksud, motivasi, tempramen, dan keinginan serta kemampuan berdisiplin diri memahami dan manghargai diri. Kecerdasan intrapersonal memang sangat sulit untuk dimengerti, akan tetapi kecerdasan ini mungkin paling penting diantara kecerdasan lain yang dimiliki oleh setiap anak.

Ketika anak berusia 4-6 tahun, anak sudah menyadari keberadaan dirinya, perasaan atau emosi yang mulai berkembang. Anak pada usia ini membutuhkan stimulus untuk dapak mengungkapkan dan mengekspresikan perasaan dan emosinya. Kerena perasaan dan emosi pada diri anak berfungsi sebagai saran untuk mengkomunikasikan kebutuhan, suasana hati, dan perasaan yang dialami anak. Untuk itu bagi orangtua dan guru kecerdasan intrapersonal juga sangat penting dikembangkan, agar anak mampu memahami diri sendiri. Agar anak mengetahui apa yang anak butuhkan dan apa yang anak tidak butuhkan, dan lebih memfokuskan mau jadi apa anak kedepannya. Anak perlu distimulus agar cerdas diri, menunjukkan emosi yang baik, memiliki kemandirian, dan mampu memotifasi diri sendiri. Memang sangat sulit bagi orangtua atau guru untuk menstimulus kecerdasan intrapersonal anak, tapi setiap stimulus yang diberikan oleh orangtua dan guru akan termemori oleh anak. setidaknya anak akan terbiasa berfikir tentang hahikat dari setiap perbuatan dalam hidupnya, serta akan selalu mempertanyakan makna dari setiap perbuatan yang dia lakukan. Walaupun belum dapat menemukan jawaban dari setiap persoalan hidup dari berbagai keyakinan, setidaknya anak stimulus yang diberikan akan membekas pada benak atau pikiran anak. 
Peneliti malihat dilapangan masih banyak orangtua dan guru mengenali lebih dalam apa yang anak butuhkan dan cara mengendalikan diri saat anak tidak dalam perasaan yang baik. Dengan mengetahui apa yang anak butuhkan, lebih memudahkan bagi orangtua untuk mengontrol emosi anak dalam belajar atau bermain. Dan untuk orang tua dan guru Kecerdasan ini ditandai dengan kemampuan memahami perasaan sendiri dan kemampuan membedakan emosi; pengetahuan tentang kekuatan dan kelemahan diri. Seseorang yang yang memilikikecerdasan ini cenderung menyukai dan efektif dalam hal berfantasi, "bermimpi", menjelaskan tata nilai dan kepercayaan, mengontrol perasaan, mengembangkan keyakinan dan opini yang berbeda, menyukai waktu untuk menyendiri, berpikir, dan merenung, introspeksi, mengetahui dan mengelola minat dan perasaan, mengetahui kekuatan dan kelemahannya.

Berdasarkan latar belakang masalah, maka rumusan masalah dalam penelitian ini dituangkan dalam bentuk pertanyaan sebagai berikut: Bagaimana perkembangan kecerdasan intrapersonal anak usia dini di kelompok B TK Negri Pembina Koto Baru Kec.Kubung Kab.Solok?

Tujun dari penelitian yang dilakukan oleh peneliti adalah Untuk mengetahuin perkembangan kecerdasan intrapersonal anak di kelompok B TK Negri Pembina Koto Baru Kec.Kubung Kab.Solok. Manfaat penelitian ini adalah hasil dari penelitian ini diharapkan dapat dijadikan sebuah petokan dalam meningkatkan kecerdasan intrapersonal anak.

\section{TINJAUAN PUSTAKA}

Menurut para ahli psikologi, usia dini sangat menentukan bagi anak dalam mengembangkan potensi yang dimiliki anak. Usia dini sering disebut dengan golden age atau usia keemasan, yang merupakan perkembangan yang sangat pesat terjadi pada usia ini. Sehingga orang tua dan guru harus memperhatikan perkembangan dan pertumbuhan anak, baik kebutuhan jasmani maupun rohani anak agar terpenuhi. Pada umumnya kecerdasan sering disebut inteligensi, sehingga orang yang cerdas berati memiliki inteligensiyang tinggi.

$\begin{aligned} \text { Menurut } & \text { Gardner } & \begin{array}{c}\text { (Musfiroh, } \\ \text { adalah } \\ \text { kemampuan }\end{array} & \text { untuk }\end{aligned}$

menyelesaikan masalah atau menghasilkan produk yang dibuat dalam satu atau beberapa budaya masyrakat". Secara terperinci Gardner (Sujiono, 2009 : hlm 176) menyatakan bahwa kecerdasan merupakan:

a) Kemampuan untuk menciptakan suatu produk yang efektif atau menyumbangkan pelayanan yang bernilai dalam budaya seseorang.

b) Sebuah perangkat keterampilan menemukan atau menciptakan bagi seseorang dalam memecahkan permasalahan dalam hidup.

c) Potensi untuk menemukan jalan keluar dari masalah-masalah yang melibatkan penggunaan pemahaman baru.

Memurut Gardner (1988) inteligensi adalah kemampuan memperoleh dan menggali pengetahuan, menggunakan pengethuan untuk memahami konsep-konsep kongkrit dan abstrak, dan menghubungkan di antara objekobjek dan gagasan-gagasan menggunakan pengetahuan dengan cara yang lebih berguna (in a meaningful way) atau efektif.

Khairani (2017, hlm. 149) Inteligensi adalah salah satu kemampuan mental, pikiran atau intelektual mausia yang merupakan bagian dari proses-proses kognitif pada urutan yang lebih tinggi (higher order cognition).

Gardner dalam Campbell dkk (2006 : hlm 202) mengungkapkan "Intrapersonal intelligence (kecerdasan intrapersonal) merupakan kemampuan untuk membuat persepsi yang akurat tentang diri sendiri dan menggunakan kemampuan semacam itu dalam merencanakan dan mengarahkan kehidupan seseorang.

Gardner dalam Umama (2016 : hlm 16) mengatakan bahwa "Kecerdasan intrapersonal adalah kemampuan seseorang untuk mengendalikan dirinya sendiri, mengembangkan potensinya, serta memiliki kemampuan untuk mengendalikan dirinya".

Intrapersonal intelligence refers to selfknowledge and the ability to act adaptively on the basis of that knowledge. This intelligence includes having an accurate picture of one's strengths and limitations; 
awareness of inner moods, intentions, motivations, and desires; and the capacity for self-discipline, self understanding, and self-esteem (Gardner \& Hatch, 1989)

Menurut gadner dalam Hyland (2011:hlm 7) bahwa: Intrapersonal Intelligence helps individuals to distinguish among their own feelings, to build accurate mental models of themselves, and to draw on these models to make decisions about their lives (difficult to observe in specific occupations, but relevant to most)

Gardner dalam Musfirah (2008: hlm 9.3) mangatakan bahwa: Kecerdasan intrapersonal adalah kemampuan memahami diri sendiri dan bertindak berdasarkan pemahaman sendiri. Kecerdasan ini merupakan akses menuju kehidupan emosional seseorang dan kemampuan membedakan emosi, pengetahuan akan kekuatan dan kelemahannya sendiri.

Thomas dkk. (2010 : hlm 43) juga mengetakan dalam buku Celebrating Every learner bahwa "....we believe that the personal intelligences are more important and that the Intrapersonal is the most important intelligence...". thomas $\mathrm{dkk}$ meyakini bahwa kecerdasan pribadi lebih penting dan kecerdasan intrapersonal adalah kecerdasan yang paling penting.

Gardner dalam Suparno (2013 : hlm 14) Inteligensi Intrapersonal adalah kemampuan yang berkaitan dengan pengetahuan akan diri sendiri dan kemampuan untuk bertindak secara adaptatif berdasar pengenalan diri itu.

Howard Gardner dalam Annier bahwa"... finds that this Intelligence is a base to our functioning. When we understand ourselves and listen to our feelings, fears, values, interests and motivations, this results in an 'effective working model' of ourselves...". Howard Gardner menemukan bahwa Intelijen ini adalah dasar untuk fungsi. Ketika kita memahami diri kita sendiri dan mendengarkan perasaan, ketakutan, nilai-nilai, kepentingan dan motivasi, hasil ini dalam sebuah 'model kerja yang efektif' dari diri sendiri.

Kecerdasan intrapersonal dapat dikembangkan, hal ini diungkap dalam tingkat pencapaian perkembangan taman kanak-kanak yang dikeluarkan oleh kementrian pendidikan nasional (2010 : hlm 14), dengan cara mengembangkan kecerdasan intrapersonal pada anak di TK dilakukan dengan bercakapcakap tentang siapa diriku, serperti apa diriku, menciptakan citra diri yang positif bahwa anak mampu dan anak bisa, memberikan kesempatan pada anak untuk bercerita tentang apa yang disukai atau tidak disukainya, membayangkan cita-citanya dikaitkan dengan bermain profesi.

Gardner menunjukkan bahwa tiap-tiap kecerdasan memiliki ciri-ciri yang dapat dikategorikan ke dalam satu jenis kecerdasan tertentu. Kecerdasan intrapersonal ditandai dengan kemampuan memahami perasaan sendiri dan kemampuan membedakan emosi, pengetahuan tentang kekuatan dan kelemahan diri Seseorang yang cerdas dalam jenis ini cenderung menyukai dan efektif dalam hal : berfantasi, "bermimpi", menjelaskan tata nilai dan kepercayaan, mengontrol perasaan, mengembangkan keyakinan dan opini yang berbeda, menyukai waktu untuk menyendiri, berpikir, dan merenung, introspeksi, mengetahui dan mengelola minat dan perasaan, mengetahui kekuatan dan kelemahan diri.

Thomas dkk. (2010, hlm. 41) juga mengetakan Characteristics dalam buku Celebrating Every learner bahwa:

"... Pursue personal interests, set realistic goals, identify and label feelings, sense their own strengths and weaknesses, are confi dent in their abilities, daydream, are insightful and reflective, are intuitive, follow their instincts, are comfortable with themselves, express a sense of justice and fairness..."

Dalam buku Metode Mengajar Multiple Intelligences, Jasmine (2007 : hlm 29) mengutarakan bahwa anak yang memiliki kecerdasan intrapersonal tinggi pada umumnya mandiri, tak tergantung pada orang lain, dan yakin dengan pendapat diri yang kuat tentang hal-hal yang kontroversial.

Howard Gardner dalam Annier
mengungkapkan bahwa:


"People with a strong Intrapersonal Intelligence are used to looking inward and figuring out their own feelings. They know their inner motivation and their own personal goals. They are introspective, deep thinkers and try to understand. They are intuitive, know the value of their intuition and act accordingly. To other people they might seem introverted and less communicative. However, fewer words often describe a full event".

Orang yang kuat kecerdasan intrapersonalnya digunakan untuk mencari tahu perasaan mereka sendiri. Mereka tahu motivasi batin mereka dan tujuan pribadi mereka sendiri. Mereka adalah introspektif, pemikir yang mendalam dan mencoba untuk memahami. Mereka adalah intuitif, tahu nilai intuisi mereka dan bertindak sesuai. Untuk orang lain mereka mungkin tampak tertutup dan kurang komunikatif. Namun, kata-kata yang lebih sedikit sering menggambarkan peristiwa penuh.

Menurut Gardner dalam suparno (2013 : hlm 48) anak yang memiliki Intrapersonal Inteligence akan menonjol dalam kepampuana sebagai berikut:

1) Dapat berkonsentrasi dengan baik

2) Kesadaran dan ekspresi perasaan-perasaan yang berbeda

3) Pengenalan diri yang dalam

4) Keseimbangan diri

5) Kesadaran akan realitas spiritual

6) Reflektif, suka kerja sendiri.

Berdasarkan paparan di atas, maka dapat di tarik kesimpulan mengenai karakteristik anak yang memiliki kecerdasan intrapersonal yaitu anak yang mandiri, penuh percaya diri, bersikap obtimis, bertanggungjawab, disiplin, bisa mengekspresikan perasaan atau emosinya dengan baik, menghargai kelebihan dan kekurangan diri sendiri, mampu menginstrospeksi diri sendiri, mempunyai perencaan yang baik, serta tidak medah terpengaruhi oleh orang lain (berkarakter kuat). Persons skilled in intrapersonal intelligence are known to have better capacity for selfdiscipline (Armstrong, 1994). Dan peneliti juga mengadopsi instrument penelitian berdasarkan kesimpulan beberapa pendapat di atas.

Dalam instrument peneliti menguraikan perkembangan kecerdasan intrapersonal anak di kelompokkan menjadi 6 aspek sebagai berikut.

\section{Mandiri}

Mandiri adalah perilaku yang tidak bergantung pada orang lain. Perkembangan sikap madiri anak dapat dilihat dari aktifitas dikelas seperti: makan sendiri tanpa bantuan orang lain, menyelasaikan tugasnya sendiri, bermain sesuai jenis yang disukai dan mampu mengurus diri sendiri tanpa bantuan atau dengan bantuan yang seperlunya.

2. Disiplin

Self-discipline is th voluntary control of one's behavior (Calkins \& Williford, 2009). Disiplin adalah nilai yang berkaitan dengan ketertiban dan keteraturan. Perkembangan kedisiplinan anak dapat dilihat dari aktivitas anak seperti: membuang sampah pada tempatnya, perapikan peralatan setelah digunakan, mentaati peraturan yang berlaku, dan berhenti bermain pada waktunya.

\section{Percaya Diri}

Rasa percaya diri perlu dimiliki anak sejak usia dini sehingga anak dapat menghargai diri sendiri dan mampu mengaktualisasikan diri. Untuk melihat perkembangan rasa percaya diri pada anak dapat dilihat dari aktivitas anak seperti: mengemukakan pendapat sederhana, percaya dengan apa yang dilakukannya, tidak malu dengan hasil karyanya, dan mengerjakan tugas secara mandiri.

\section{Tanggung jawab}

Tanggung jawab adalah nilai yang terkait dengan kesadaran untuk melakukan dan menanggung segala sesuatunya.Tanggung jawab artinya mengakui perbuatan dan risiko akibat perbuatan yang dilakukan. Perkembangan rasa tanggungjawab yang dimiliki anak dapat dilihat dari aktivitas anak seperti: melaksanakan tugas yang diberikan oleh guru, menjaga barang yang dimilikinya, membersihkan peralatan makan setelah digunakan, dan melaksanakan kegiatan sendiri sampai selesai.

5. Mampu Mengekspresikan kegiatan 
Mengekspresikan kegiatan perlu dilakukan anak agar anak dapat menyampaikan perasaan suka dan tidak suka terhadap kegiatan yang sedang dilakukannya. Aspek perkembangan ini dapat dilihat dari aktivitas anak seperti: mampu menceritakan tentang diri sendiri, dapat melihatkan mimik wajah saat melakukan kegiatan yang disenanginya, mampu mengekspresikan perasaannya, dan mau berpisah dengan orang tuanya.

6. Mampu memperbaiki diri

Sikap memperbaiki diri juga harus ditanamkan pada diri anak sejak dini dengan tujuan supaya anak dapat melakukan perubahan dan tidak mudah merasa puas dengan apa yang sudah dicapainya. Untuk aspek ini dapat dilihat dari aktivitas anak seperti: anak menerima kegagalan dan keberhasilan dalam menyelesaikan tugas, mencoba kembali hal yang belum berhasil, menerima saran dan kritik, serta anak melakukan perubahan dengan sungguhsungguh.

\section{METODE}

Metode yang digunakan dalam penelitian ini adalah metode deskriptif, karena data yang terkumpul dan analisisnya lebih bersifat kualititaf dimana peneliti mendeskripsikan hasil observasi, catatan anekdot dan wawancara dengan narasumber terkait kecerdasan intrapersonal anak di kelompok B. Peneliti menggunakan metode ini atas dasar penjelasan Sugiyono (2011, hlm. 15) bahwa "metode kualitatif digunakan untuk mendapatkan data yang mendalam, suatu data yang mengandung makna". Berdasarkan penjelasan tersebut maka data yang terkumpul dan analisisnya lebih bersifat kualitatif, dimana peneliti mendeskripsikan hasil observasi dan wawancara terkait perkembangan kecerdasan intrapersonal anak. Pendekatan yang digunakan dalam penelitian ini adalah pendekatan kuantitatif.

Proses penelitian ini dengan persiapan yaitu memilih masalah, peneliti memilih kecerdasan intrapersonal anak sebagai subjek yang akan diteliti, kemudian peneliti mencari informasi tentang masalah yang akan diteliti. Dengan studi pendahuluan dan studi pustaka, peneliti merumuskan masalah dalam bentuk pertanyaan dan menyusun intrumen yang diperlukan, berupa bentuk pedoman observasi dan wawancara. Untuk pengumpulan data yang dibutuhkan pada penelitian ini, peneliti menentukan sumber data yang akan diteliti, setelah itu dilanjut dengan pengumpulan data. Data yang diperoleh dianalisis dan dideskripsikan sebagai jawaban dari rumusan masalah, dan di simpulkan.

Teknik pengumpulan data dalam penelitian ini melakukan teknik observasi (pengamatan), wawancara (interview), catatan anekdot dan studi dokumentasi. Studi Dokumentasi diperlukan untuk pengumpulan data pendukung berupa foto dan video yang diambil pada saat kegiatan pembelajaran dan laporanlaporan. Penelitian ini menggunakan instrumen pengumpulan data yaitu lembar observasi, catatan anekdot, pedoman wawancara dan alat rekam untuk menunjang pengambilan data berikut adalah kisi-kisi instrumen penelitian :

Data yang dikumpulkan dalam penelitian ini meliputi data hasil observasi, dan wawancara terkait dengan kecerdasan intrapersonal anak. Analisis data pada penelitian ini akan dikategorikan melalui pengolahan statistik deskriptif. Menurut Sugiono (2013, hlm 147) Statistik deskriptif adalah statisti yang digunakan untuk menganalisis data dengan cara mendeskripsikan atau menggambarkan data yang telah terkumpul sebagaimana adanya. Dalam penelitian ini statistik deskriptif digunakan kerena peneliti hanya ingin mendeskripsikan data sample, dan tidak ingin membuat kesimpulan yang berlaku untuk populasi dimana sampel diambil. Mendeskriptisikan data dimaksudkan untuk mengetahui gambaran umum variabel. Variabel yang akan dianalisis meliputi setiap aspek dan indikator variabel kecerdasan intrapersonal anak.

\section{TEMUAN DAN PEMBAHASAN}


Penelitian yang dilakukan adalah deskripsi tentang Perkembangan kecerdasan intrapersonal anak kelompok B TK Negeri Pembina Koto Baru kecamatan Kubung Kabupaten Solok. Terkait dengan penelitian ini, peneliti telah melakukakan observasi dan wawancara yang difokuskan pada aspek-aspek perkembangan kecerdasan intrapersonal anak yakni, aspek mandiri, disiplin, percaya diri, tanggungjawab, mengekspresikan kegiatan, dan mampu memperbaiki diri.

Berdasarkan hasil data yang didapat dari observasi dan wawancara di kelompok B TK Negeri Pembina Koto Baru dengan jumlah anak 15 orang. Diperoleh bahwa anak yang perkembangan kecerdasan intrapersonalnya berada pada tingkat pencapaian berkembang sangat bagus (BSB) ada 8 orang anak, 5 orang anak dengan tingkat pencapaian berkembang sesuai harapan (BSH). Dan sisanya 2 orang anak dengan tingkat pencapaian mulai berkembang (MB). Hal tersebut dipengaruhi oleh pembiasaan dirumah atau disekolah.

Untuk lebih jelasnya dapat dilihat pada grafik berikut :

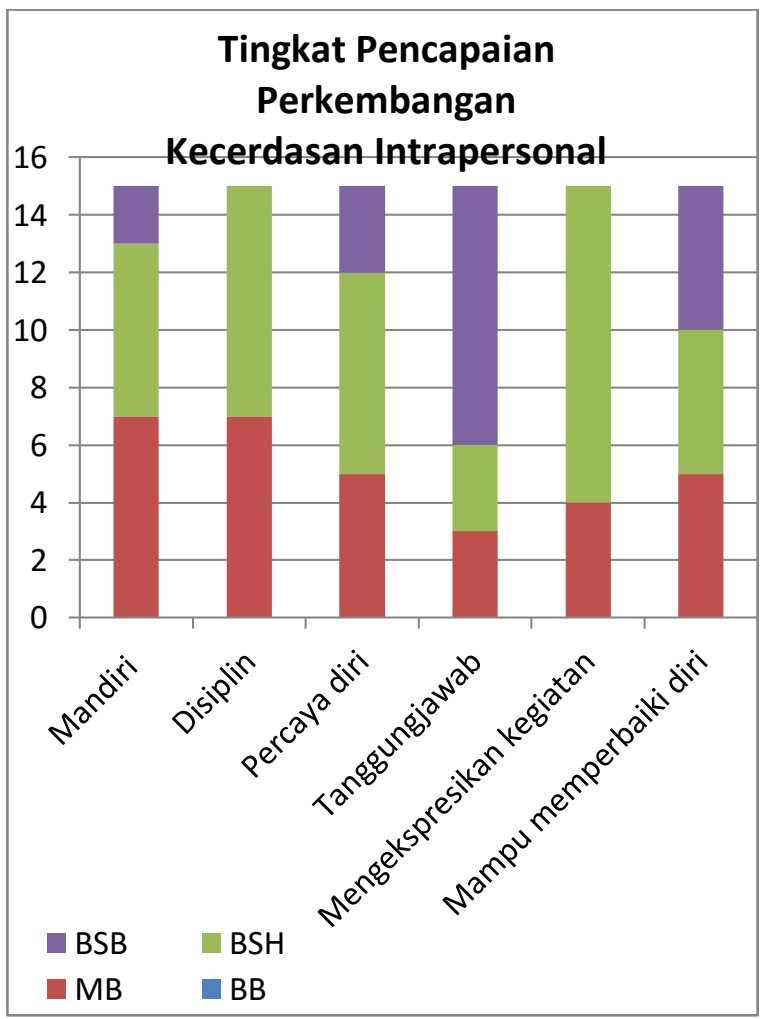

Gambar 4.1

Grafik Interval Tingkat Pencapaian Perkembangan Kecerdasan Intrapersonal Anak
Dalam sugiono (2013: hlm 191) bahwa cara mengembangkan kecerdasan intrapersonal pada anak disekolah ada 2 cara yaitu: 1) Menciptakan citra diri positif. Guru dapat memberikan self image, citra diri yang baik pada anak, dengan menampilkan sikap yang hangat namun tegas pada anak sehingga anak tetap memiliki sikap hormat pada guru. Selain itu guru yang menghormati dan peduli pada anak didiknya, akan membuat guru lebih mudah memberikan perhatian, penghargaan, dan penerimaan pada anak didiknya. 2) Menciptakan suasana yang mendukung pengembangan kemampuan intrapersonal dan penghargaan diri anak.

Tadkiroatun Musfiroh (hlm 9.13) menyatakan bahwa kecerdasan intrapersonal pada anak dapat dikembangkan dengan berbagai cara, meliputi bermain,bermain, bercakap-cakap, dan bercerita. Kegiatan ini bertujuan untuk menstimulus kemampuan anak memahami ciri dan minat diri, kemampuan menilai diri, kemampuan menikmati kegiatan, kemampuan menyatakan maksud dan ekspresi diri, dan kemampuan berdisiplin dan kontrol diri.

Kecerdasan intrapersonal penting bagi setiap orang yang ingin menguasai kendali atas kehidupannya dan mencapai keberhasilan dan keaman. Keterampilan dalam kecerdasan intrapersonal dalam penelitian ini meliputi mandiri, disiplin, percaya diri, tanggung jawab, mengekspresikan kegiatan, dan mampu memperbaiki diri.

Kecerdasan intrapersonal anak kelompok B TK Negeri Pembina Koto Baru Kecamatan Kubung Kabupaten Solok dalam aspek mandiri berada pada tingkat pencapaian berkembang sesuai harapan (BSH). Karena dalam aspek ini terdapat 8 orang anak yang berada pada tingkat BSH dan BSB. Dalam aspek mandiri terdapat empat indikator yaitu pertama mankan sendiri tanpa bantuan orang lain, kedua menyelesaikan tugasnya, ketiga bermain sesuai jenis yang disukai, dan keempat mampu mengurus diri sendiri. Indikator aspek mandiri terdapat dalam buku Cheklist Indikator Perkembangan Anak 0 - 6 Tahun (Umama, M.Kom). 
Kecerdasan intrapersonal anak kelompok B TK Negeri Pembina Koto Baru Kecamatan Kubung Kabupaten Solok dalam aspek disiplin berada pada tingkat pencapaian berkembang sesuai harapan (BSH). Kerena kebenyakan anak berada padatikat BSH yaitu 8 orang anak. dalam aspek disiplin terdapat empat indikator yaitu pertama membuang sampah pada tempatnya, kedua merapikan peralatan setelah digunakan, ketiga mentaati peraturan yang berlaku, dan keempat berhenti bermain pada waktunya. Indikator aspek disiplin terdapat dalam buku Cheklist Indikator Perkembangan Anak 0 - 6 Tahun (Umama, M.Kom).

Kecerdasan intrapersonal anak kelompok B TK Negeri Pembina Koto Baru Kecamatan Kubung Kabupaten Solok dalam aspek percaya diriberada pada tingkat pencapaian berkembang sangat baik (BSB). Kerena kebanyakan anak berada pada tingkat pencapaian BSB dan BSH yaitu 10 orang anak. Dalam aspek percaya diri terdapat empat indikator yaitu pertama mengemukankan pendapat sederhana, kedua percaya dengan apa yang dilakukan, ketiga tidak malu dengan hasil karya dan keempat mengerjakan tugas secara mendiri. Indikator aspek percaya diri terdapat dalam buku Cheklist Indikator Perkembangan Anak 0 - 6 Tahun (Umama, M.Kom).

Kecerdasan intrapersonal anak kelompok B TK Negeri Pembina Koto Baru Kecamatan Kubung Kabupaten Solok dalam aspek tanggung jawab berada pada tingkat pencapaian berkembang sangat baik (BSB), karena kebanyakan anak berada pada tingkat pencapaian BSB dan BSH yaitu 12 orang anak. Aspek tanggung jawab terdiri dari empat indikator yaitu pertama melaksanakan tugas yang diberikan guru, kedua menjaga barang yang dimilikinya, ketiga membersihkan peralatan makan sendiri, keempat melaksanakan kegiatan sendiri sampai selesai. Indikator aspek tanggungjawab terdapat dalam buku Cheklist Indikator Perkembangan Anak 0 - 6 Tahun (Umama, M.Kom).

Kecerdasan intrapersonal anak kelompok B TK Negeri Pembina Koto Baru Kecamatan Kubung Kabupaten Solok dalam aspek mengekspersikan kegiatan berada pada tingkat pencapaian berkembang sesuai harapan (BSH), karena kebanyakan anak berada pada tingkat pencapaian BSH yaitu 11 orang anak. Aspek mengekspresikan kegiatan terdapat empat indikator yaitu yang pertama mempu bercerita tentang diri sendiri, kedua melihatkan mimik wajah saat melakukan kegiatan, ketiga dapat mengekspresikan perasaan, dan yang keempat mau berpisah dengan orang tua. Indikator aspek mengekspresikan kegiatan terdapat dalam buku Cheklist Indikator Perkembangan Anak 0 - 6 Tahun (Umama, M.Kom).

Kecerdasan intrapersonal anak kelompok B TK Negeri Pembina Koto Baru Kecamatan Kubung Kabupaten Solok dalam aspek mampu memperbaiki diri berada pada tingkat pencapaian berkembang sesuai harapan (BSH), karena kebanyakan anak berada pada tingkat pencapaian BSH dan BSB yaitu 10 orang anak. aspek mampu memperbaiki diri terdapat empat indikator yaitu yang pertama menerima kegagalan dan keberhasilan, kedua mau mencoba kembali hal yang belum berhasil, ketiga menerima saran dan kritik, dan keempat melakukan kegiatan dengan sungguh-sungguh. Indikator aspek mampu memperbaiki diri terdapat dalam buku Cheklist Indikator Perkembangan Anak 0 - 6 Tahun (Umama, M.Kom).

Kecerdasan intrapersonal yang menonjol dalam diri anak sering kelihatan pendiam, lebih suka bermenung, dan bekerja sendiri.

\section{KESIMPULAN}

Berdasarkan dari hasil analisis data yang diperoleh peneliti pada bagian sebelumnya dapat disimpulkan bahwa perkembangan kecerdasan intrpersonal anak secara menyeluruh sudah berada pada tingkat pencapaian berkembang sangat baik (BSB). Karena kebanyakkan anak berada pada tingkat pencapaian BSB yaitu 8 orang, dan 5 orang dengan pencapaian BSH. Sedangkan aspek perkembangan kecerdasan intrapersonal anak sebagai berikut:

1. Perkembangan kecerdasan intrapersonal anak kelompok B TK Negeri Pembina Koto Baru Kecematan Kubung Kabupaten Solok dalam aspek mandiri berada pada 
tingkat pencapaian perkembang berkembang sesuai harapan (BSH).

2. Perkembangan kecerdasan intrapersonal anak kelompok B TK Negeri Pembina Koto Baru Kecematan Kubung Kabupaten Solok dalam aspek disiplin berada pada tingkat pencapaian berkembang sesuai harapan (BSH).

3. Perkembangan kecerdasan intrapersonal anak kelompok B TK Negeri Pembina Koto Baru Kecematan Kubung Kabupaten Solok dalam aspek percaya diri berada pada tingkat pencapaian berkembang sangat baik (BSB).

4. Perkembangan kecerdasan intrapersonal anak kelompok B TK Negeri Pembina Koto Baru Kecematan Kubung Kabupaten Solok dalam aspek tanggungjawab berada pada tingkat pencapaian berkembang sangat baik (BSB).

5. Perkembangan kecerdasan intrapersonal anak kelompok B TK Negeri Pembina Koto Baru Kecematan Kubung Kabupaten Solok dalam aspek mengekspresikan diri berada pada tingkat pencapaian berkembang sesuai harapan (BSH).

6. Perkembangan kecerdasan intrapersonal anak kelompok B TK Negeri Pembina Koto Baru Kecematan Kubung Kabupaten Solok dalam aspek mampu memperbaiki diri berada pada tingkat pencapaian berkembang sangat baik (BSB)

\section{IMPLIKASI}

Penelitian ini memunculakan berbagai implikasi yang dapat menjadi pertimbangan bagi para praktisi pendidikan dalam rangka mengelola pembelajaran atau pun dalam kegiatan penelitian lainnya. Berdasarkan hasil penelitian dan kesimpulan yang diperoleh, maka implikasi dalam penelitian ini adalah sebagai berikut. Dengan penelitian ini diharapkan pada pendidik untuk bisa memberi stimulus melalui pembelajaran yang menari dan menyenangkan untuk mengembangkan kecerdasan intrapersonal anak kelompok B TK Negeri Pembina Koto Baru. Pihak sekolah diharapkan dapat memberikan kebebasan kepada anak untuk meningkatkan kecerdasan intrapersonal anak. Disarankan untuk lebih memahami perkembangan kecerdasan intrapersonal anak agar dapat mengoptimalkan kecerdasan yang dimiliki anak. Hasil penelitian ini direkomendasikan untuk melakukan penelitian lanjutan dalam peningkatan kecerdasan intrapersonal anak.

\section{DAFTAR PUSTAKA}

Annier, Hoekstra. Intrapersonal Intelligence. Bulgium. Inspirit Internasional Comunications

Arikunto, Suharsimi. (2010). Prosedur Penelitian Suatu Pendekatan Praktik. Jakarta: Rineka Cipta.

Cambell dkk (2006). Metode Praktis Pembelajaran Berbasis Multiple Intelligences. Depok: Intuisi Press

Fadhli, M. (2010). Pemikiran Howard Gardner dalam pendidikan anak usia dini. Indria, Jurnal Ilmiah Pendidikan Prasekolah dan Sekolah Awal. 1 (1). 2508-004X. Hlm. 8586.

Gardner, H (2003). Multiple Intelligences. Batam. Interaksara

Hyland, A (2011). Multiple Intelligences Curriculum and Assessment Project. NAIRTL. University College Cork

Idris, M (2014). Meningkatkan Kecerdasan Anak Usia Dini melalui Mendongeng. Jakarta. PT. Luxima Metro media

Jeong,W. Dkk (2013). Young Children's RolePlaying for Enhancing Personal Intell Multiple Intelligences Theory. USA. International Research in early childhood education. Vol 4. No.1, Page 54

Khairani, M (2017). Psikologi Belajar. Yogyakarta. Aswaja Pressindo

Lwin, M. dkk. (2008). How To Multiply Your Child's Intelligence: Cara Mengembangkan Berbagai Komponen Kecerdasan. Penerjemah: Christine Sujana. Jakarta: Indeks

Musfiroh, T.(2008). Pengembangan Kecerdasan Majemuk. Jakarta: Universitas Terbuka.

PERMENDIKBUD Nomor 137 tahun 2014 tentang Standar Pendidikan Anak Usia Dini

Riduwan. (2006). Dasar-Dasar Statistika. Bandung: Alfabeta

Sugiyono. (2014). Metode Penelitian Pendidikan. Bandung: PT Alfabeta. 
Sujiono, Y (2009). Konsep Dasar Pendidikan Anak Usia Dini. Jakarta. PT Indeks

Suparno, P. (2013). Teori Intelligensi Ganda Dan Aplikasi Di Sekolah. Yogyakarta: Kanisius

Thomas,R. dkk. (2010) Celebrating Every learner. San Francisco. Jossey-Bass

Tora, Y. (2015). Faktor-faktor yang Mempengaruhi Perkembangan Kecerdasan Intrapersonal Pada Anak Kelompok B TK KI Hahar Dewantoro 5. E.Journal FIP Universitas Negeri Gorontalo. Hlm 8

Tahir,F. (2015). Deskripsi Kecerdasan Intrapersonal Pada Anak Kelompok B TK Herlina. E.Jurnal FIP Universitas Gorontalo. Hlm 7

Umama (2016). Pojok Bermain Anak. Jogjakarta. Stiletto Book 